\title{
GEORGE BERNARD SHAW
}

\section{Letter to the producer of The Silver Tassie (1929)}

Whitehall Court

London

Charles B. Cochran

Apollo Theatre

London

My dear Cochran,

I really must congratulate you on The Silver Tassie before it passes into the classical repertory. It is a magnificent play; and it was a magnificent gesture of yours to produce it. The highbrows should have produced it; you, the unpretentious showman, did, as you have done so many other noble and rash things on your Sundays. This, I think, will rank as the best of them. I hope you have not lost too much by it, especially as I am quite sure you have done your best in that direction by doing the thing as extravagantly as possible. That is the worst of operating on your colossal scale; you haven't time to economise; and you lose the habit of thinking it worth while.

No matter! a famous achievement. There is a new drama rising from unplumbed depths to sweep the nice little bourgeois efforts of myself and my contemporaries into the dustbin; and your name will live as that of the man who didn't run away. If only someone would build you a huge Woolworth Theatre (all seats $6 d$ ) to start with O'Casey and O'Neill, and no plays by men who had ever seen a $f_{5} 5$ note before they were 30 or been inside a school after they were 13 , you would be buried in Westminster Abbey. Bravo!

G. B. S.

(from The Times, 26 Nov I929) 